\title{
Statement on Access to Original Research Materials
}

\section{in Libraries, Archives, and Manuscript Repositories}

Drafted by the Committee on Manuscripts Collections of the Rare Books and Manuscripts Section of the Association of College and Research Libraries. Approved as policy by the ACRL Board of Directors in January 1974.

1. It is the responsibility of a library, archives, or manuscript repository to make available to qualified researchers, as defined by the respective institutions, on equal terms of access, research materials in its possession. Because the accessibility of material depends on knowing of its existence, it is the responsibility of a repository to inform researchers of the collections in its custody. This may be accomplished through a card catalog, inventories and other internal finding aids, a published guide and reports to NUCMC where appropriate, and the freely offered assistance of staff members.

2. To protect and insure the continued accessibility of the material in its custody, the repository may impose several conditions.

a. The repository may limit the use of fragile or unusually valuable materials so long as suitable reproductions are made available for the use of all researchers.

b. All materials must be used in accordance with the rules of and under the supervision of the repository. Each repository should publish and furnish to potential researchers its rules governing access and use. Such rules must be equally applied and enforced.

c. The repository may refuse access to unprocessed materials, so long as such refusal is applied to all researchers.

d. Normally, a repository will not send research materials for use outside its building or jurisdiction. Under special circumstances a collection or a portion of it may be loaned or placed on deposit with another institution.

e. The repository may refuse access to an individual researcher who has demonstrated such carelessness or deliberate destructiveness as to endanger the safety of the material.

3. Each repository should publish a suggested form of citation crediting the repository and identifying items within the collection for later reference. Citations to copies of ma- terials in other repositories should include the location of the originals.

4. A repository should advise the researcher that he and his publisher have the sole responsibility for securing permission to publish from unpublished manuscripts in which literary property rights are retained or to publish any extensive quotation from copyrighted works. Manuscripts cannot be used for publication without due regard for common law rights, literary rights, property rights, and libel laws. The user assumes legal responsibility for observing these rights. A repository should, to the best of its ability, inform the researcher about known retention of literary rights.

5. A repository should not grant exclusive use of materials to any person or persons, or conceal the existence of any body of material from any researcher unless required to do so by law, donor, or purchase stipulations.

6. A repository should, whenever possible, inform a researcher of parallel research by other individuals using the same papers. It may supply names upon request.

7. Repositories are committed to preserving manuscript and archival materials and to making them available for research as soon as possible. At the same time, it is recognized that every repository has certain obligations to protect confidentiality in its records in accordance with law and that every private donor has the right to impose reasonable restrictions upon his papers to protect confidentiality for a reasonable period of time.

a. It is the responsibility of the repository to inform researchers of the restrictions which apply to individual collections or record groups.

b. The repository should discourage donors from imposing unreasonable restrictions.

c. The repository should, whenever possible, require a specific time limit on all restrictions.

d. The repository should periodically reevaluate restricted records and work toward providing access to material no longer harmful to individuals or to national interest.

Single reprint copies of this statement are available free of charge from the ACRL Office, 50 E. Huron St., Chicago, IL 60611. Multiple copies are $20 \%$ each. 